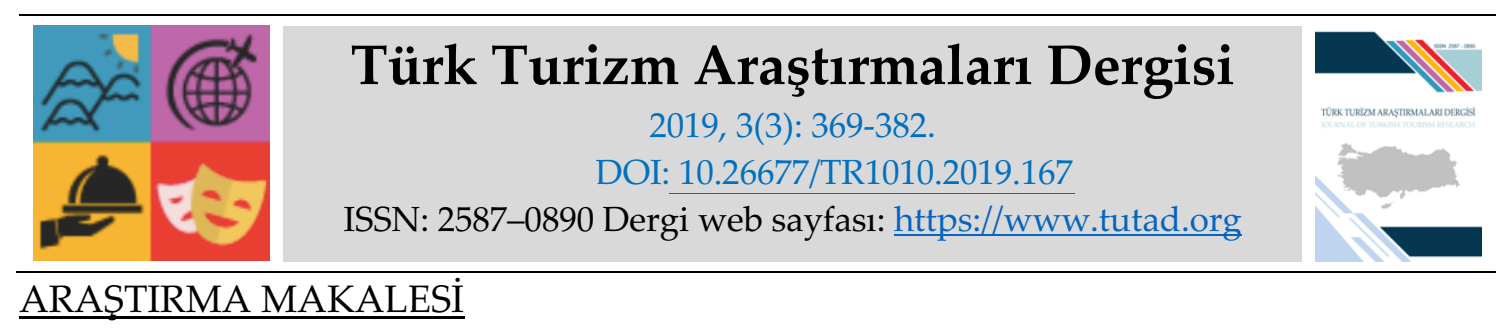

\title{
İnsan Kaynakları Yönetimi İşlevi Olarak İş Değerleme - Ücret Yönetimi Süreci ve Karşılaşılan Sorunlar: Turizm İşletmeleri Üzerine Kavramsal Bir Değerlendirme
}

\author{
Doç. Dr. Elbeyi PELİT, Afyon Kocatepe Üniversitesi, Turizm Fakültesi, e-posta: \\ elbeyipelit@aku.edu.tr \\ ORCID: https://orcid.org/0000-0002-6418-801X
}

Öğr. Gör. Faruk GÖKÇE, Burdur Mehmet Akif Ersoy Üniversitesi, Yeşilova İsmail Akın MYO, eposta:farukgokce@hotmail.com

ORCID: https://orcid.org/0000-0002-4100-2171

\section{Öz}

İş değerleme ve ücret yönetimi; bir işin diğer işlere göre değerinin belirlenmesi ve karşılaştırılması, ücret strateji ve politikalarının geliştirilmesi, ücret yönetimi sisteminin tasarımlanması uygulanması ve sürdürülmesiyle ilgili faaliyetleri kapsayan bir süreçtir. İnsan kaynakları yönetiminin bir işlevi olan iş değerleme ve ücret yönetimi, işletmelerin başarılı olma yolunda önem vermesi gereken bir husustur. Turizm işletmeleri ise emek-yoğun olma özelliği sebebiyle insan kaynakları yönetiminin daha fazla önem kazandığı işletmelerdir. Turizm işletmelerinin başarısı, etkili bir insan kaynağına sahip olmasının yanında, başarılı bir ücret yönetimi sürecine de bağlıdır. Bu çalışmanın amacı, önemli bir insan kaynakları yönetimi işlevi olan iş değerleme ve ücret yönetimi kapsamında turizm işletmelerinde yaşanan sorunların genel bir bakış açısıyla değerlendirilmesini sağlamaktır. Bu kapsamda, ilgili literatürde konuyla ilgili daha önceki çalışmalar incelenerek iş değerleme ve ücret yönetiminin kapsamı, ücret sistemleri ve turizm işletmelerinde iş değerleme ve ücret yönetimi kapsamındaki sorunlar ayrıntılı bir şekilde açıklanmıştır. Ayrıca bu süreçte yaşanan sorunların çözümünde; insan kaynakları yönetimi biriminin rolü ve önemi vurgulanmıştır. Sonuç olarak çalışmada, nitel araştırma yöntemlerinden literatür taraması ve gözlem tekniği kullanılarak iş değerleme ve ücret yönetimi sürecinde yaşanan sorunlar ortaya konmuş ve sorunların giderilmesi hususunda işletme yöneticilerine ve araştırmacılara öneriler getirilmiştir.

Anahtar Kelimeler: İnsan Kaynakları Yönetimi, İş Değerleme, Ücret Yönetimi, Turizm İşletmeleri, Turizm İşletmelerinde İş Değerleme ve Ücret Yönetimi Sorunları.

Makale Gönderme Tarihi: 25.04.2019

Makale Kabul Tarihi: 07.07.2019

\section{Önerilen Atıf:}

Pelit, E. ve Gökçe, F. (2019). İnsan Kaynakları Yönetimi İşlevi Olarak İş Değerleme - Ücret Yönetimi Süreci ve Karşılaşılan Sorunlar: Turizm İşletmeleri Üzerine Kavramsal Bir Değerlendirme, Türk Turizm Araştırmaları Dergisi, 3(3): 369-382.

(C) 2019 Türk Turizm Araştırmaları Dergisi. 


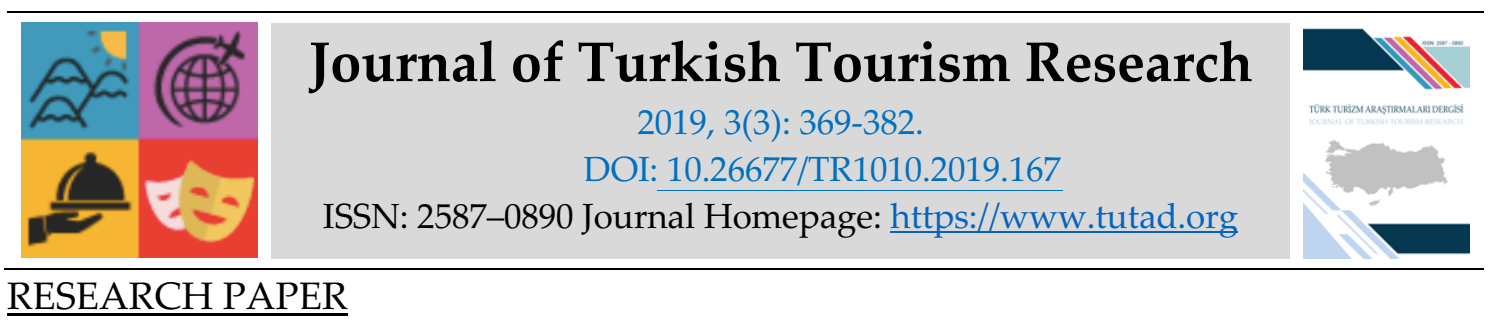

\title{
Job Evaluation - Wage Management Process as a Function of Human Resources Management and Problems Encountered: A Conceptual Evaluation on Tourism Enterprises
}

Assoc. Prof. Dr. Elbeyi PELIT, Afyon Kocatepe University, Faculty of Tourism, e-mail: elbeyipelit@aku.edu.tr ORCID: https://orcid.org/0000-0002-6418-801X

Lecturer Faruk GÖKÇE, Burdur Mehmet Akif Ersoy University, Yeşilova İsmail Akın Vocational School, e-mail:farukgokce@hotmail.com ORCID: https://orcid.org/0000-0002-4100-2171

\begin{abstract}
Job evaluation and wage management; It is a process that covers the activities related to the design, implementation and maintenance of the wage management system. Job evaluation and wage management, which is a function of human resources management, is an issue that businesses should give importance to in the way of success. Tourism enterprises are the enterprises where human resources management becomes more important because of its laborintensive feature. Therefore, the success of tourism enterprises depends on a successful wage management process as well as having an effective human resource. The aim of this study is to provide an overview of the problems experienced in tourism enterprises within the scope of business valuation and wage management, which is an important human resources management function. In this context, in the related literature, the previous studies on the subject were examined and the scope of the job evaluation and wage management, wage systems and the problems in job evaluation and wage management in tourism enterprises were explained in detail. Also, in the process of solving the problems experienced; The role and importance of human resources management unit is emphasized. As a result, in the study, the problems experienced in the process of job evaluation and wage management were put forward and suggestions were given to business managers and researchers about the problems.
\end{abstract}

Keywords: Human Resource Management, Job Evaluation, Wage Management, Tourism Enterprises, Job Evaluation and Wage Management Problems in Tourism Enterprises.

Received: 25.04 .2019

Accepted: 07.07.2019

Suggested Citation:

Pelit, E. and Gökçe, F. (2019). Job Evaluation - Wage Management Process as a Function of Human Resources Management and Problems Encountered: A Conceptual Evaluation on Tourism Enterprises, Journal of Turkish Tourism Research, 3(3): 369-382.

(c) 2019 Türk Turizm Araştırmaları Dergisi. 


\section{Gíriş}

Ekonomik anlamı ile mal ve hizmet üretiminde harcanan insan emeğinin karşılığı, başka bir ifadeyle "işgücünün fiyatı" ücret olarak adlandırılmaktadır. İşletme bilimi açısından ise ücret, işletmenin varlığını sürdürebilmesi ve ekonomik amaçlarına ulaşabilmesi doğrultusunda çalışana yapılan ödeme olarak nitelendirilir (Ertürk, 2006). Ücret, bir yandan işletmede üretkenlik ve verimi arttıran bir araç rolü oynadığ 1 gibi diğer yandan da işgöreni işletmeye bağlayan ekonomik motivasyon aracıdır. Bir bakıma ücret, işgörenin işletmeye giriş nedeni olduğu gibi aynı zamanda onun işletmede sürekli çalışma nedenini de oluşturur (Ergül, 2006:94).

İşletmelerde ücret ve diğer ödemelerin yönetimi, iş değerleme ile birlikte yönetilen önemli bir insan kaynakları yönetimi işlevidir. Çünkü bireyi işletmeye çekebilmek, devamlılığını sağlayabilmek ve verimli çalışmaya güdeleyebilmek için cazip bir ücrete ihtiyaç vardır. Aynı zamanda bu ücret düzeyi, maliyetler açısından işletmeye aşırı yük ve sorun olmayacak bir miktar olmalıdır. O halde iş değerleme ve ücret yönetimi, çalışan ve işletme açısından çok hassas dengeler üzerinde kurulmalıdır (Şahin, 2010:138).

Turizm işletmelerinde uygulanan iş değerleme ve ücret yönetimi, hizmet sunum özelliği nedeniyle işletmeler arasında farklılıklar gösterebilmektedir. Farklılıklar, müşteri ile doğrudan iletişimde bulunan ve geri planda çalışan işgörenlere yapılan ücretlendirmeden kaynaklanmaktadır. Ayrıca ücret yönetiminde temel ücretin yanı sıra primler, ikramiyeler ve sosyal yardımlar gibi ücret eklentileri ile çalışma saatleri, fazla çalışma, ücret artışları gibi özelliklerin de dikkate alınması gerekmektedir. Bunda amaç, işgörenlerin ücretini belirlerken işletme içinde ve işletme dışında eşitlik ve adaletin sağlanmasıdır (Yenipınar, 2005:149).

Turizm işletmelerinde insan kaynakları yönetimi birimi kapsamında gerek iş değerleme ve ücret yönetimi uygulamalarının yeterince uygulanamama sorunu gerekse bu süreçte yaşanan sorunlar, bu çalışmanın çıkış noktasını oluşturmuştur. Bu çerçevede çalışmanın amacı, önemli bir insan kaynakları yönetimi işlevi olan iş değerleme ve ücret yönetimi kapsamında turizm işletmelerinde yaşanan sorunların genel bir bakış açısıyla değerlendirilmesini sağlamaktır. Bu çalışma, konuyla ilgili gerçekleştirilmiş kuramsal ve uygulamalı çalışmalar ile mevcut uygulamalar dâhilinde elde edilen bilgiler doğrultusunda ikincil veri analizi ve yazarların turizm sektöründeki gözlemlerine dayanılarak hazırlanmıştır. Çalışmada özellikle, konuyla ilgili taraflara öneriler getirilmesi ve gerçekleştirilecek uygulamalı çalışmalara bir alt yapı oluşturulması hedeflenmektedir. Çalışmada ayrıca söz konusu bu süreçte yaşanan sorunlara özet bir bakış sunulmuş/değerlendirilmiş ve konuyla ilgili olarak insan kaynakları yöneticilerinin bu süreçteki rolleri ve neler yapılabileceğine ilişkin ilgili taraflara ve araştırmacılara öneriler sunulmuştur.

\section{ISS DEĞERLEME VE ÜCRET YÖNETIMİ SÜRECININN KAPSAMI VE TURIZMM IŞSETMELERI AÇISINDAN ÖNEMI}

Ücret; işgücü karşılığında, çalışana işveren tarafından verilen para veya ürün (Tekin ve Şenol, 2013:202) olarak tanımlanmaktadır. Daha geniş ve genel anlamı ile ücret; doğa, emek ve sermaye şeklindeki üretim faktörlerinin en önemlilerinden biri olan emeğin bedelidir (Yalçın, 1999:170). Ücret; çoğunlukla temel ücret, değişken ücret ve ek yararlardan/sosyal yardımlardan oluşan bir paketi veya toplamı ifade etmektedir (Ataay ve Acar, 2008:401). Temel ücret, yapılan işin değerine ya da işgörenlerin becerilerine ya da yetkinliklerine göre belirlenmektedir. Temel ücretler, mevcut işler arasındaki değer farklılıklarının ortaya çıkarılması ve buna göre işlerin ücretlendirilmesiyle ya da işlerin yapılması için gerekli yetkinliğin veya becerilerin belirlenmesi ve bunların ücretlendirilmesiyle belirlenebilmektedir. Örneğin bir makine operatörünün temel ücreti, farklı iş değerleme yöntemleri kullanılarak belirlenecek işin değerine göre, saatlik $20 \mathrm{TL}$ 
olarak tespit edilebilir (Demir ve Acar, 2014:103). Değişken ücret ise esas olarak işgörenlerin performansı/katkısı ile ilişkili olarak verilen ücreti ifade etmektedir. Birey, takım/grup veya örgüt düzeyinde performans ile ücret arasında ilişki kurularak değişken ücret belirlenebilmektedir (Milkovich, Newman ve Gerhart, 2011:12). Ücretin miktarı belirlenirken göz önünde bulundurulması gereken bazı kriterler vardır. Bu kriterler; devlet politikası ile belirlenen, işgörenin şahsî ve ailevî durumu, meslekî tecrübe, mahallî geçinme şartları, gece ve gündüz işçiliklerinde ücret farklılıkları ve işin niteliği şeklinde sıralanabilir (Isaac, 1940).

Söz konusu unsurları kapsayan ve belirli kriterler çerçevesinde oluşturulan ücretin nasıl ve neye göre belirleneceği, çalışanlara nasıl ödeneceği, insan kaynakları yönetiminin önemli işlevlerinden biri olan "ücret yönetimi" konusu içinde incelenmektedir.

"Ücret ve maaş yönetimi" ve "ücretleme/ücretlendirme" diye de adlandırılan iş değerleme ve ücret yönetimi işlevi, işletmelerde çalışan işgörenlerin işlerini değerleme ve ücretlendirilmelerine dair politikayı, yapıyı, sistemi ve uygulamaları kapsamaktadır. Ücret politikaları işletmenin ücret felsefesine, amaçlarına ve stratejisine uygun olarak ödüllendirme süreçlerinin nasıl tasarımlanması ve yönetilmesi gerektiğini ve ücret düzeyiyle ilgili olarak örgütün piyasadaki rakiplerine kıyasla ücretlerinin ne durumda olacağını, kısacası ücrete yönelik "dış eşitliği" göstermektedir (Milkovich ve Newman, 1984:264; Demir ve Acar, 2014:103-104).

İsgörenler, bağlı olduğu işletmeye bilgi, beceri ve yetenekleriyle katkıda bulunurlar. Bunun karşıllğı olarak da adil ücret isterler. İ̧̧letmeler de kişiye bilgi, beceri ve yeteneklerini kullanacağı bir ortam sağlar. Aynı zamanda işletmeler, kâr ederken çalışanlara başarılarına göre ücret vermek durumundadır. Bunun yanında, rekabet düzeyinin yüksek olduğu ülkelerde ise işletmeler, hiç kuşkusuz istediği çalışanı elde tutabilmek için daha yüksek ücret ödemek durumunda kalmaktadırlar. Öte taraftan söz konusu bu ücret miktarının belirlenmesinde birtakım etkenler rol oynamaktadır. Bu kapsamda ücret yönetimini etkileyen birtakım söz konusu bu etkenleri; iç ve dış olarak etkenler olarak ikiye ayırmak mümkündür. Ücretin belirlenmesini etkileyen iç ve dış etkenlere Şekil 1'de yer verilmiştir.

Şekil 1. Ücret Yönetimini Etkileyen İç ve Dış Unsurlar

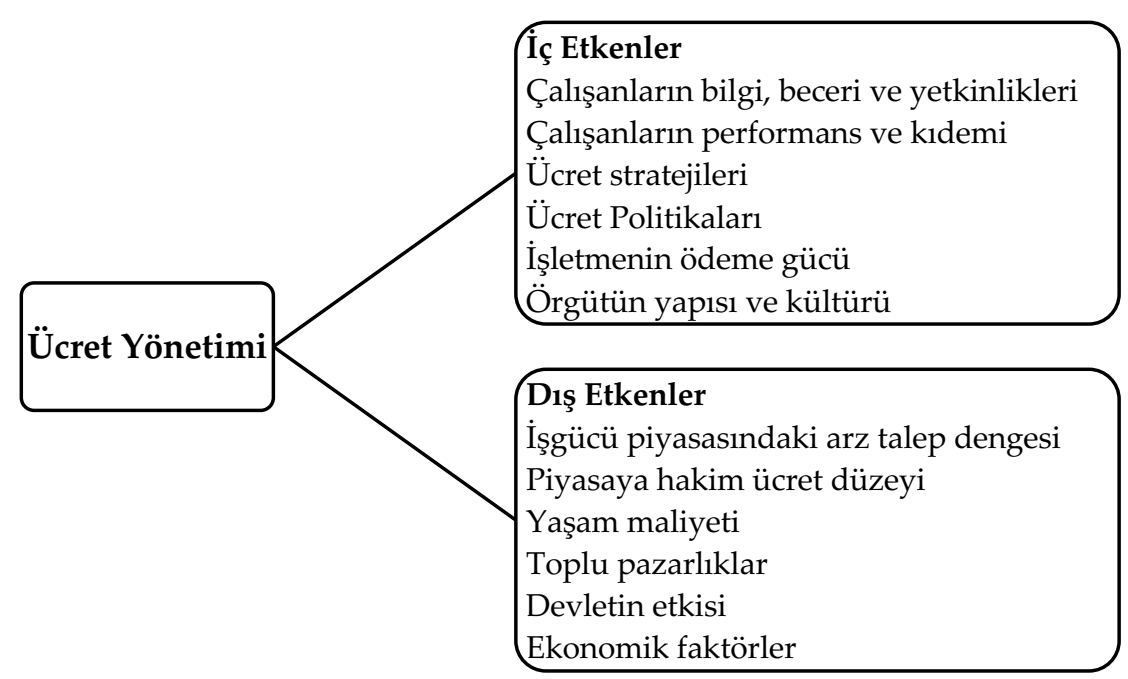

Kaynak: Işığıçok, (2011).

Ücret konusu, ekonomik ve sosyal yaşamda çeşitli etkileri olan çok yönlü bir konudur. Bir taraftan emeği karşılığında çalışan insanların gelirini ve yaşam düzeylerini tayin edici bir unsur iken; diğer taraftan gerek endüstrinin gelişmesine etki eden önemli bir maliyet öğesi, gerekse de milli gelirin çeşitli gelir grupları arasındaki dağılım tarzını, o toplumdaki sosyal adaletin ortaya 
çıkma oranını gösteren bir gösterge olarak çok yönlü önem arz eder. Çünkü bireyi işletmeye çekebilmek, devamlılığını sağlayabilmek ve verimli çalışmaya güdeleyebilmek için cazip bir ücrete ihtiyaç vardır. Aynı zamanda bu ücret düzeyi, maliyetler açısından işletmeye aşırı yük ve sorun olmayacak bir miktar olmalıdır. O halde ücret yönetimi, çalışan ve işletme açısından çok hassas dengeler üzerinde kurulmalıdır (Şahin, 2010:138). Diğer yandan ücret yönetimi, iş değerleme sürecini takip eden bir yönetim sürecini kapsar. Genel olarak çalışanın değil, işin değerlenmesi olan iş değerleme, bir işin diğer işlere göre değerinin belirlenmesi ve karşılaştırılmasıdır (Gürüz ve Özdemir Yaylacı, 2009:232).

İş Değerleme ve Ücret Yönetimi: Ücret yönetimi, “iş değerleme” sürecinin bir devamı niteliği taşımaktadır. Bu bağlamda iş değerleme, işlerin içerikleri ve değerleri bakımından göreceli olarak farklılıkları ve benzerliklerine dayalı bir ödeme mekanizmasının geliştirilmesi ve sürdürülebilmesi amacını taşır (Milkovich ve Boudreau, 1991). İş değerleme, turizm sektörünün taşıdığı özellikler gereği sıkça başvurulması gereken bir tekniktir. Özellikle hizmet kalitesi ve çalışan performansının soyut özellikteki hizmet başarımları üzerinden ölçülmesi, bu duruma somutluk kazandırabilecek esaslara ihtiyacı beraberinde getirmektedir. Böylece çalışanların değerlendirilirken temel alınan esasların şeffaf bir şekilde iletilmesi, çalışanlar arasında örgüte güven sağlanması ve adalet duygusunun inşa edilebilmesi açısından iş değerleme, turizm sektöründe stratejik açıdan daha önemli konum kazanmaktadır. Bilindiği gibi örgütlerde ücret ödemede adaletli yaklaşım, etkili bir motivasyon aracı olarak kabul edilmektedir (Wu, Sturman ve Wang, 2013). İş değerleme, çalışanların eşit işe eşit ücret kapsamında adil ücret ve teşvik almalarının sağlanmasına temel kazandıran bir uygulama olarak kabul edilmektedir. Buna paralel olarak literatürde iş değerlemenin, çalışanların örgüte güvenleri ve bağlllıklarında etkili bir unsur olduğu vurgulanmaktadır (Erbaş ve Dursun, 2016:326).

İş değerlemesi; bir işletmede mevcut işler arasındaki değer farklılıklarını ortaya çıkaran bir karşılaştırma yöntemi olup insan kaynakları yönetimi sürecinin en önemli fonksiyonlarından birisidir. Her işin değeri nitelik ve özelliğinin değişikliğine bağlı olarak birbirinden farklıdır (Dağdeviren, Akay ve Kurt 2004:89). İş değerlemenin kapsamına; basit olarak işlerle ilgili bilgileri toplama, karşılaştırma ve kullanıma uygun sıralama listeleri oluşturma girmektedir. Bu listeler, işletmelerde farklı pozisyonlar için yapılandırılmış ödeme hiyerarşisinin temelidir. (French, 2003:405). Bununla birlikte iş değerlemesi, çalışanların işlerinin işletmeye kattığı değerin işlerin içeriğine göre belirlendiği bir süreçtir. Bu süreçte, çaba, beceri, sorumluluk ve çalışma koşulları gibi faktörler temel alınabilir. İş değerlemesi işletme içi eşitliğin sağlanması açısından önem taşımaktadır. Ayrıca tüm işlerin sistematik olarak karşılaştııılabilmesine olanak sağlanmaktadır (Tahiroğlu, 2002:210).

İş değerleme yaklaşımları temel olarak ikiye ayrılmaktadır. Bunlardan birincisi pazar temelli yaklaşımdır. Diğer yaklaşım ise işletme içerisinde işletmenin stratejileri doğrultusunda her işin örgütteki rolünü değerleme yolu ile bir hiyerarşi oluşturmayı hedefleyen iş içerikli değerlemedir. Ancak bu işletme içi değer belirleme yaklaşımını desteklemek için kıyas kabul edilen işlerin pazardaki değerini de dikkate almak önem taşımaktadır (Martocchio, 2004:217). Bu bağlamda, iş değerleme yöntemlerinde işlerin göreceli önemlerini belirlemeye yönelik iki yaklaşım söz konusudur. Bunlar sayısal olan ve olmayan iş değerleme yöntemleridir. Sıralama ve sınıflama yöntemleri sayısal olmayan iş değerleme yöntemleridir. Bu yaklaşım işi bir bütün olarak ele almaktadır. Puanlama ve faktör karşılaştırması ise sayısal iş değerleme yöntemleri arasındadır. Bu yaklaşım ise, işi öğelerine ve faktörlerine ayırmaktadır (Kelly, 1972:28; Ataay, 1990:23; Akıncı, Kasalak ve Yurcu, 2015:44).

Sayısal Olmayan İş Değerleme Yöntemleri: İşe karşı iş olarak da bilinen bu yöntemler, işlerin bir diğeri ile karşılaştırılabilmesi için bütünsel olarak değerinin belirlenmesi anlayışına dayanır. $\mathrm{Bu}$ grupta en yaygın kullanılan yöntemler, sıralama ve sınıflama yöntemleridir. Sıralama 
yöntemi, genellikle küçük firmalar tarafından kullanılan bir yöntemdir (Yüksel, 1998:193). Bu yöntem; en eski, uygulaması en kolay ve en hızlı olan iş değerleme yöntemidir. Bu yöntem, işlerin öğelerine veya faktörlerine ayrılmamasını, bütün olarak ele alınmasını ve işler arasındaki farklılık derecesinin belirlenmesinde sayısal ifadelerin kullanılmamasını kapsar. Yöntemde işler, bütün olarak karşılaştırılmakta ve önemlerine göre sıralanarak işler hiyerarşisinde yerleri belirlenmektedir (ILO, 1986:27).

Sınıflama ya da derecelendirme yöntemi ise işi bütün olarak ele alması ve işleri sınıflandırmak için puan ya da parasal değerleri kullanmaması yönünden sıralama yöntemi ile benzerlik gösterir (ILO, 1986:31). Sınıflama yöntemi, işlerin sorumluluk, beceri gibi yönlerini dikkate alarak iş sınıflarının ve derecelerinin belirlenmesini içerir. Bu yöntem, işlerin karşılaştırılmasında ve önem sırasına konmasında tasarlanmış ölçüt ve ölçekler kullanmaktadır (Can, Akgün ve Kavuncubaşı, 2001:217).

Sayısal İş Değerleme Yöntemleri: Sayısal olmayan iş değerleme yöntemleri basit ve kolay uygulanabilir olma özelliklerine sahiptirler. Ancak bu yöntemlerin nesnelliği bir işin diğer işe göre niçin daha fazla değerli olduğu konusunda tartışma götürmektedir. İş değerleme yöntemlerinde en sık kullanılan sayısal iş değerleme yöntemleri işleri bütün olarak ele almak yerine, çeşitli faktörlere göre değerlendirdiğinden sayısal olmayan yöntemlere göre daha nesnel ve bilimsel olarak kabul görmektedir (Elizur, 1980:28). Puanlama yöntemi ve faktör karşılaştırma yöntemi bu grupta kullanılan iş değerleme yöntemleridir (Akıncı, Kasalak ve Yurcu, 2015:44).

Puanlama yöntemi, 1936 yılında Merrill Lott tarafından geliştirilen, iş değerleme çalışmalarında en sık kullanılan sayısal bir yöntemdir (Elizur, 1980:25). Puanlama yöntemi, üretim birimindeki mevcut işlerin göreceli değerlendirilmesi sonucu, oluşan her bir işin faktörlere, alt faktörlere ve faktör derecelerine göre incelenerek puanlanması ve derecelendirilmesidir (Eraslan ve Arıkan, 2004:140). Derece düzeyleri ilgili iş için faktörlerin tanımlanmasında ortaya çıkacak belirgin farklılıkları yansıtan düşükten yükseğe puan değerlerini ifade etmektedir. İşler her bir faktör ve ifade edilen derece ile değerlenir. İşin hiyerarşi içerisindeki yeri her faktör için verilmiş puanların toplamı ile belirlenir (Rock ve Berger, 1991:81). Böylece işlerin dereceleri yükseldikçe göreceli önemleri artacak ve ücret sıralamasında yükselecektir. (Decenzo ve Robbins, 1988:483). Puanlama yönteminde işin göreceli değeri, birçok faktör yardımıyla ve her bir faktöre belli bir sistem dahilinde sayısal puanlar verilmesiyle elde edilen toplam puan aracilı̆̆ıyla belirlenir (Akün, 1984:319). Puanlama yöntemi ülkemizde yapılan birçok iş değerleme çalışmasında başarıyla kullanılmıştır (Ataay, 1990:54).

Faktör karşılaştırma yöntemi, diğer bir sayısal iş değerlendirme yöntemidir. Bu yöntem puanlama yönteminden türetilmiştir. Faktör karşılaştırma yöntemi puanlama yönteminin temel ilkelerine dayanmaktadır. Bu yöntemde de puanlama yönteminde olduğu gibi işler bütün olarak ele alınmamakta, belirli faktörlere göre değerlendirilmektedir. İş değerleme yapılırken anahtar işleri kullanılması, işleri karşılaştırma biçim ve faktörlere parasal değerler verilmesi açısından puanlama yönteminden ayrılmaktadır. Diğer yönden de faktör karşılaştırma yöntemi sıralama ve puanlama yöntemlerinin özelliklerini birleştirmektedir (ILO, 1986:51).

Faktör karşılaştırma yöntemi, temel olarak geniş kabul görmüş dört faktörden yararlanmaktadır. $\mathrm{Bu}$ faktörler; yetenek, çaba, sorumluluk ve çalışma koşullarından oluşmaktadır. Yöntem bu faktörlere uygun biçimde her işi diğer tüm işlerle karşılaştırarak bir hiyerarşi oluşacak şekilde işlerin sıralanmasını gerçekleştirir (Rock ve Berger, 1991:79). Faktör karşılaştırma yönteminde işler parasal karşılıkları belirlenmiş çeşitli faktörlere göre değerlendirilmektedir. Bu nedenle değerlenen işlerin doğrudan ana (kök) ücreti belirlenmektedir. (Can, Akgün ve Kavuncubaşı, 1998:221). Yöntem, uygulanmasındaki güçlüklerden dolayı yaygın olarak kullanılmamaktadır. 
İş değerlemenin amac1, objektif kriterlere göre işlerin önem ve güçlüklerinin belirlenmesi ve eşit önem ve güçlükteki işlere eşit ücret ödenmesidir. "Eşit işe eşit ücret" ilkesinin hayata geçirilmesi ise paternalist ücret yönetimi uygulamalarının ortadan kaldırılması, işyeri yönetimi ile çalışanlar arasında ilişkilerin geliştirilmesi, verimliliğin artırılması, çalışanların kendi kendilerini değerlendirebilmeleri ve teşvik etmeleri anlamına gelmektedir (England, 2000).

Turizm sektörünün emek-yoğun olma özelliği, insan kaynakları yönetimine verilen/verilmesi gereken önemi daha da artırmakla birlikte turizm işletmelerindeki insan kaynağının yönetim biçimine yönelik uygulamaların işletmelerin başarısında önemli faktör olması, bu işletmelerde insan kaynakları yönetimini yürüten birimlere de daha fazla sorumluluk yüklemektedir (Pelit, 2015:62). İşgörenlerin ücret konusunda işletmeden beklentileri genel anlamda kendilerine adil davranılmasıdır. İnsan kaynakları yönetimi kapsamında yürütülen ücret yönetimi, emek-yoğun olan turizm işletmelerinde bu sorumluluğu daha da artırmaktadır.

Turizm işletmelerinde uygulanan ücret yönetimi, insan kaynakları yönetimi biriminin önemli bir işlevidir. İnsan kaynakları yönetimi biriminin temel işlevlerinden olan ücret yönetiminin etkin bir şekilde yürütülmesi, işgörenlerin ve dolayısıyla işletmenin verimli çalışmasını sağlayacaktır (Erdem, 2004:41). Turizm işletmelerinde ücret düzeyi; işgücü arz ve talep düzeyleri, tarafların pazarlık gücü, devletin ücret düzeylerine müdahaleleri, aynı iş kolunda veya benzer ve rakip işletmelerde geçerli ücret düzeyleri, işgörenlerin niteliği ve hayat pahalılığı gibi faktörlerin yanında; işin nitelikleri, güçlüğü, işin gerektirdiği eğitim ve deneyimler, iş ortamının özellikleri de göz önüne alınarak işgöreni tatmin edici bir biçimde belirlenebilir (Özdemir ve Akpınar, 2002:92).

Genellikle düşük vasıflı, düşük ücretli faaliyetleri içerdiği belirtilen (Webster, 2014:696) turizm işletmelerinde ve diğer işletme türlerinde, ücretlerin düzenlenmesi amaciyla farklı ücret sistemlerinden yararlanılmaktadır. Bu sistemlerle ilgili gruplandırma bazı kaynaklarda; doğrudan işgücü piyasası verilerine göre, işe veya işi yapan bireye göre olabileceği gibi (Benligiray, 2003); temel ücret sistemleri, yüzde ücret sistemleri (Yenipınar, 2005) şeklinde ya da ana ücret sistemleri, performansa dayalı ücret sistemleri ve primli ücret sistemleri (Özgen, Öztürk ve Yalçın, 2005) olarak gruplanabilmektedir. Benzer şekilde turizm işletmelerinde de kullanılan ücret sistemleri ise temel ücret sistemleri; primli ücret sistemleri, sabit ücret sistemi, yüzde yöntemi ve kazanç (kâr) paylaşımı şeklinde sıralanabilir (Akoğlan Kozak, 2012:172).

Temel Ücret Sistemleri: Personele ödenecek ücretin, önceden belirlenmiş zamana ve belirli bir standarda veya iş miktarına göre hesaplanmasını öngören sistemlerdir. Bu grup başlığı altında yer alan başlıca temel (kök) ücret sistemleri; zaman esasına dayalı ücret sistemleri, performansa dayalı ücret sistemleri ve özendirici ücret sistemleri olarak siralanabilir. Otellerde, seyahat acentalarında, restoran işletmelerinde dolayısıyla hemen hemen her turizm işletmesinde genellikle yaygın olarak kullanılan ücret sistemidir (Çetin, Dinç Özcan ve Arslan, 2014:178).

Primli Ücret Sistemleri: Belirlenen kök bir ücrete; zamandan, maliyetten elde edilen tasarrufun, verim ve kalitenin artışı sonucunda elde edilen gelirin bir kısmının çalışana ek olarak verilmesine dayanan bir sistemdir. Primli ücret sistemleri; miktara göre, kaliteye göre tasarruf esasına göre ve işyerine devama göre primli ücret sistemleri olarak sıralanabilir (Isaac, 1940). Otel işletmelerinde satış-pazarlama departmanındaki işgörenlere, satılan oda/yatak başına verilen primler örnek olarak verilebilir.

Sabit Ücret Sistemi: Maktu ya da değişmez ücret de denilen bu ücret sistemi toplu iş sözleşmeleriyle belirlenir. Toplu iş sözleşmeleri ve iş kanunun tanıdığı diğer hakları da kapsamaktadır. Personel, yaptığı işin karşılığında işveren tarafından vaat edilen veya toplu sözleşmelerle belirlenen miktarı yine önceden belirlenen sürenin sonunda alır. Asgari ücret ve aylık olarak ödenen sabit ücretler bu grup altında sıralanabilir (Akoğlan Kozak, 2012:173). 
Otellerde, seyahat işletmelerinde, yiyecek-içecek işletmelerinde ve diğer turizm işletmelerindeki sabit ödenen belli ücretler, bu ücret sistemine örnek olarak verilebilir.

Yüzde Yöntemi: Bu sistemde işgörenin ücreti, belirli bir yüzdeye göre belirlenen değerden oluşur. Bazı durumlarda işgörene hem çalıştığı zamana göre hem de yüzde usulüne göre ücret ödenmektedir. Yüzde usulü ücrette müşteriler kendilerine yapılan hizmetin karşıllı̆̆ olarak bir miktar para öderler. Bu miktar, hesap pusulasına yapılacak ödemenin belirli bir yüzdesi olarak eklenmesi şeklinde gerçekleşir. Yüzde olarak hesaplanan bu ödemeler işveren tarafından alıkonur ve daha sonra işgörenlere ödenir. Bu sistemin müşterinin isteğine göre ödediği para olan bahşişle karıştırılmaması gerekir (Budak, Arpacı ve Tolay, 2017:26). Yiyecek-içecek işletmelerinde bahşiş haricinde servis personeline ödenen ücretler buna örnek olarak verilebilir.

Kazanç (Kâr) Paylaşımı: Bu yöntem; işgörene, örgütten aldığı normal ücretlerine ek olarak işletmenin kâr elde etmesi durumunda elde edilen kârdan belirli bir oranda pay ödenmesi esasına dayanır (bu oran genellikle \%25'dir). Kârdan pay ödenmesi uygulaması genellikle iki şekilde yapılır. İlki, işgörene her kâr elde edilen dönem sonunda elde edilen kârdan belirli bir oranda pay ödenmesi; ikincisinde ise direkt ödeme yapılmayıp kârdan ayrılan payın bir fonda toplanarak işgörene emeklilik, hastalık, işsizlik vb. gibi durumlarda ödenmesidir (Akoğlan Kozak, 2012). Seyahat acentalarındaki tur personeline, sattığı tur başına belirli oranda kârdan pay verilmesi, bu ücret sistemine örnek olarak verilebilir.

Yukarda açıklanan ücret sistemleri genel olarak turizm işletmelerinde kullanılan ücret sistemleridir. Turizm işletmesinin türüne ve yapısına göre değişkenlik gösterebilen bu yöntemlerden en yaygın uygulananının temel ücret sistemleri olduğunu ifade etmek mümkündür. Bununla birlikte sabit ücret sisteminin de ülke genelinde işletmeler bazında uygulanan en yaygın ücret sistemi olduğu ifade edilebilir. Asgari ücret gibi yaygın bir ücret yönteminin sabit ücret sistemine girmesi, bu sistemin en yaygın kullanılan ücret sistemi olmasını sağlamaktadır.

İnsan kaynakları yönetiminin temel işlevlerinden biri olan ücret yönetimini başarısı, o işi yapacak işgörenin nitelikleri ve performans sonuçları ile yakından ilişkilidir (Aksoy, 2005). Bu bağlamda, turizm işletmeleri açısından ücret yönetimi sürecinin etkin bir şekilde uygulanması, işletmenin varlık sebebi olan karlılığına ve diğer turizm işletmeleriyle olan rekabette öne geçmesine katkı sağlayacaktır.

\section{TURIZM ISŞLETMELERINDE IŞ DEĞERLEMESİ VE ÜCRET YÖNETIMI KAPSAMINDAKI SORUNLAR VE ÇÖZÜMÜNDE INSAN KAYNAKLARI YÖNETIMI BIRIMININ ROLÜ}

Turizm işletmelerinde iş değerlemesi, yapılan işe göre ücret sistemi geliştirmeye olanak sağlayan ve işgörenlerin kendilerini iyi hissetmeleri ve adil davranıldığını düşünmelerine yol açan, insan kaynakları yönetimi birimi sorumluluğunda gerçekleştirilen önemli bir görevdir. Turizm işletmelerinin yapısı gereği insan ilişkilerine dayanması, iş değerleme yapılırken hassasiyetle davranılmasını ve adaletli bir şekilde işlerin değerlemesini zorunlu kılmaktadır.

Turizm işletmelerinde müşteriye sunulan hizmetin kalitesi, büyük ölçüde bu hizmeti sunan işgörenin ödüllendirilmesine bağlıdır. Turizm işletmelerinde işgörenin moralinin müşteriye yansıdığı bilinmektedir. Örneğin; morali bozuk olan işgören işini o anda iyi bir şekilde yerine getiremeyeceği için hem işgörenin psikolojik durumu hem de sunulan hizmetin yetersizliği hızla müşteriye de yansıyacaktır (Yenipınar, 2005:155). 
Turizm işletmeleri, ücreti önemli bir maliyet unsuru olarak görmektedir. Bu nedenle sektörde ücretleri artırmama, dondurma hatta indirme, işgücü sayısını azaltma, düşük ücretle işgören çalıştırma ve kalifiye olmayan personel istihdam etme gibi uygulamalara gidebilmektedirler. Ücretleme ile ilgili amaç, strateji ve politikalar; gelecek birkaç yıl içerisinde ücret uygulamaları açısından işletmenin nerede olmak istediği ve olmak istediği noktaya nasıl (hangi sistem ve uygulamaları kullanarak) ulaşacağı ile ilgilidir (Armstrong, 2009:746). Diğer yandan turizm işletmeleri genellikle sezonluk yoğunluğa göre personel istihdam edebilmektedir. Emeğe dayalı üretimin olduğu turizm işletmeleri, hizmeti üreten insan olduğu için diğer işletmelere göre işgücünün daha önemli bir yere sahip olduğu işletmelerdir. Bu nedenle talepte meydana gelen değişiklikler, işgücüne olan ihtiyaç miktarının da talebe bağlı olarak değişmesi sonucunu doğurmaktadır. Turizm işletmelerinin bu özelliği gereği işletmeler, nitelikli iş göreni işletmeye çekmede ve elde tutmada zorluk çekmektedirler (Şahin, 2015:374). Bu yüzden işletmede oluşturulacak adil bir ücret yönetimi sistemi, turizm işletmesinin değişken sezon yapısına ve iş gören devir hızının yüksek olmasına rağmen işletmenin başarısına olumlu yönde katkı sağlayabilecektir.

Bir başka açıdan bakıldığında, insanın insana hizmet ettiği turizm işletmelerinde müşteri memnuniyeti büyük ölçüde iş görenlerin onlara güler yüzle sunduğu hizmete bağlı olduğu söylenebilir. Turizm işletmelerinde çalışan iş görenlerin çalıştıkları yerde mutlu olması, başarılı bir hizmet sunumu açısından hayati öneme sahiptir. Aynı zamanda iş görenlerin duygusal emeklerini olumlu yönde misafirlere yansıtmasında çalıştıkları yerde mutlu olmaları önemli bir faktördür. İş görenlerin işyerinde mutlu olmasının en önemli araçlarından biri ücrettir (Özdemir ve Akpınar, 2002). Bu nedenle iş görenler her şeyden önce emeklerinin karşılığı hak ettikleri ücreti almayı beklerler. Bunu sağlamanın en etkili yolu ise işletme içerisinde adil bir ücret sisteminin oluşturulmasıdır. Adil ve etkin bir ücret yönetimi için başarılı iş değerleme sürecine ihtiyaç vardır. İş değerleme ve ücret yönetimi sayesinde nitelikli iş görenler işletmeye çekilmekte, mevcut olanlar elde tutulmakta ve motive edilmektedir. Başarılı bir iş değerleme sürecinin ardından adil bir ücret yönetiminin gerçekleştirilememesi, iş görenlerin motivasyonunun düşmesine, devamsızlık ve iş gören devir oranının yükselmesine, performans ve verimliliğin düşmesine dolayısıyla uzun vadede turizm işletmelerinin hizmet kalitesinin düşmesine neden olmaktadır (Şahin, 2015:374).

Ücretin bu denli hassas bir konu olmasının yanı sıra turizm sektörünün genel itibariyle kırılgan yapıs1; turizm işletmelerindeki ücret yönetimi konusunu daha da önemli hale getirmektedir. Bununla birlikte turizm işletmelerindeki insan kaynakları yönetimi biriminin sorumluluğu diğer işletme türleriyle kıyasla daha stratejik öneme sahiptir. Ücret yönetimi kapsamında karşılaşılan sorunların da en aza indirgenmesi ve ortadan kaldırılması önemli bir husus olarak ifade edilebilir. Tablo 1'de turizm işletmelerinde ücret yönetimi kapsamında karşılaşılan sorunlar ve sorunların çözümünde insan kaynakları yönetimi biriminin rolüne yer verilmiştir.

Tablo 1. Turizm İşletmelerinde İş Değerleme ve Ücret Yönetimi Kapsamında Karşılaşılan Sorunlar ve Sorunların Çözümünde İnsan Kaynakları Yönetimi Biriminin Rolü

\begin{tabular}{|c|c|c|}
\hline $\begin{array}{c}\text { Turiz̧letmelerinde Ücret } \\
\text { Yönetimi } \\
\begin{array}{c}\text { Kapsamında } \\
\text { Karşışlaşın Sorunlar }\end{array}\end{array}$ & $\begin{array}{c}\text { Sorunların Çözümünde İnsan Kaynakları } \\
\text { Yönetimi Biriminin Rolü }\end{array}$ & $\begin{array}{c}\text { İnsan Kaynakları Yönetimi Birimlerine } \\
\text { Yönelik Çözüm Önerileri }\end{array}$ \\
\hline $\begin{array}{c}\text { Uygun Ücret } \\
\text { Sisteminin Seçimi }\end{array}$ & $\begin{array}{l}\text { Ücret yöntemi belirlenirken her iş, kendi içinde } \\
\text { değerlendirilmeli ve işe en uygun yöntem } \\
\text { seçilebilir. }\end{array}$ & $\begin{array}{l}\text { Turizm işletmelerinden her biri (işletme } \\
\text { türü ve özellikleri dikkate alınarak) için } \\
\text { uygulanacak ücret yönteminin en uygun } \\
\text { olanını seçmek, iş görenleri tatmin etmesi } \\
\text { açısından işletmenin yararına olacaktır. } \\
\text { Uygun olacak yöntemin belirlenmesinde iş }\end{array}$ \\
\hline
\end{tabular}




\begin{tabular}{|c|c|c|}
\hline & & $\begin{array}{l}\text { görenlerin duygusal emekleri de göz } \\
\text { önünde bulundurulmalıdır. }\end{array}$ \\
\hline $\begin{array}{l}\text { Personel Devir } \\
\text { Hızının Yüksek } \\
\text { Olması }\end{array}$ & $\begin{array}{l}\text { Turizm işletmelerinde sektörün yapısıyla } \\
\text { alakalı bir durum olan mevsimsellik sorunu, } \\
\text { personel sirkülasyonunun da hızlanmasına } \\
\text { neden olmaktadır. }\end{array}$ & $\begin{array}{l}\text { Personelin kısa süreli çalıştıktan sonra } \\
\text { işten ayrılma fikrinin oluşmasını } \\
\text { engellemek için çalışma şartları ve } \\
\text { ücretleme sistemi daha iyileştirilebilir. }\end{array}$ \\
\hline $\begin{array}{l}\text { İş görenlerin Daha } \\
\text { Yüksek Ücret İsteği }\end{array}$ & $\begin{array}{l}\text { Turizm işletmelerindeki iş görenlerin sektörün } \\
\text { emek-yoğun yapısından dolayı daha yüksek } \\
\text { ücret taleplerine karşı insan kaynakları } \\
\text { yönetimi personelinin ücret yönetimi sürecini } \\
\text { hassasiyetle yürütmesi beklenir. }\end{array}$ & $\begin{array}{l}\text { Turizm işletmelerinde, insan kaynakları } \\
\text { yönetimi birimleri tarafından iş görenlerle } \\
\text { birlikte ücret bilgilendirmesi toplantıları } \\
\text { düzenlenebilir. Bu sayede, iş görenler } \\
\text { ücret sistemleri hakkında kendilerine adil } \\
\text { davranıldığı konusunda emin olabilirler. }\end{array}$ \\
\hline $\begin{array}{l}\text { Turizm Sektörünün } \\
\text { Mevsimsellik Sorunu }\end{array}$ & 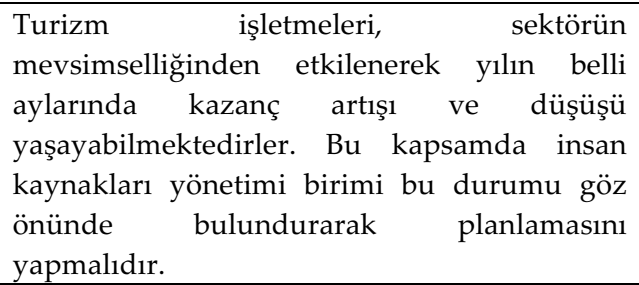 & $\begin{array}{l}\text { Turizm işletmelerinin } r \text { kazanç } \\
\text { dalgalanmalarına karşı işgörenlerin } \\
\text { çalışma durumunu iyi ayarlaması ve ücret } \\
\text { sistemini de ona göre planlaması } \\
\text { gerekmektedir. }\end{array}$ \\
\hline $\begin{array}{l}\text { Cinsiyete Göre } \\
\text { Farklılaşan Ücret }\end{array}$ & $\begin{array}{l}\text { Turizm işletmelerinde departmana göre } \\
\text { farklılaşan kadın ya da erkeğin lehine ücret } \\
\text { farklılıkları gözlemlenmektedir. İnsan } \\
\text { kaynakları yönetimi biriminin çabasıyla bu } \\
\text { durum ortadan kaldırılabilir. }\end{array}$ & $\begin{array}{l}\text { Turizm işletmelerinde uygulanan ücret } \\
\text { farklılıkları, departmanlardan ziyade } \\
\text { cinsiyete göre de değişebilmektedir. Bu } \\
\text { durum karşısında insan kaynakları } \\
\text { yönetimi birimi, eşitlikten ödün vermeyip } \\
\text { cinsiyete değil yapılan işin niteliğine göre } \\
\text { ücret belirleme yoluna gitmelidir. }\end{array}$ \\
\hline $\begin{array}{l}\text { Fazla Mesailerin } \\
\quad \text { Ücrete } \\
\text { Yansitılmaması }\end{array}$ & $\begin{array}{l}\text { Turizm işletmelerinin yoğun sezonlardaki iş } \\
\text { gören bulamama sorunu, iş görenlerin fazla } \\
\text { mesaiye kalmalarını beraberinde } \\
\text { getirmektedir. Bununla birlikte işletme için iş } \\
\text { görenin maliyeti de arttığından işletmeler fazla } \\
\text { mesaiye kalan iş görenlere ücret yerine izin } \\
\text { verebilmektedir. }\end{array}$ & $\begin{array}{l}\text { Turizm işletmeleri için iş görenlerin fikri } \\
\text { sorulmadan yapılan bu uygulama, uzun } \\
\text { vadede işletmenin zararınadır. Bunun } \\
\text { yerine iş görenin fazla mesai konusundaki } \\
\text { fikirlerine önem verilmeli ve ona göre } \\
\text { politikalar belirlenmelidir. }\end{array}$ \\
\hline $\begin{array}{l}\text { Başarı } \\
\text { Ödüllendirmelerinde } \\
\text { Ücret Kullanılmaması }\end{array}$ & $\begin{array}{l}\text { Turizm işletmelerinin genellikle motive edici } \\
\text { ve iş göreni güdüleyici uygulamalarından biri } \\
\text { de haftanın/ayın personeli seçme } \\
\text { uygulamalarıdır. Bu uygulamanın sonucunda } \\
\text { insan kaynakları yönetimi birimi aracılığıyla } \\
\text { belirlenen para ödülleri, iş göreni daha da } \\
\text { motive edecektir. }\end{array}$ & $\begin{array}{l}\text { Turizm işletmelerindeki insan kaynakları } \\
\text { yönetimi birimi tarafından belirlenecek } \\
\text { politika ile iş görenlerin ödüllenmelerinde } \\
\text { ücret kullanılarak iş görenlerin ödüle karşı } \\
\text { daha motive şekilde davranış } \\
\text { sergilemeleri sağlanabilir. }\end{array}$ \\
\hline $\begin{array}{c}\text { Turizmde } \\
\text { Sendikalaşmanin } \mathrm{Az} \\
\text { Olması }\end{array}$ & $\begin{array}{l}\text { Turizm işletmeleri, özel sektör işletmeleri } \\
\text { arasında neredeyse en az sendikalaşmanın } \\
\text { görüldüğü işletmelerdir. Bu durum, toplu ücret } \\
\text { sözleşmeleri gibi iş görenlerin lehine fırsatları } \\
\text { kaçırmalarına sebep olabilir. İnsan kaynakları } \\
\text { yönetimi birimi, sendikalaşma konusunda iş } \\
\text { görenleri ve işletmeyi yönlendirmelidir. }\end{array}$ & $\begin{array}{l}\text { Turizm işletmelerindeki insan kaynakları } \\
\text { yönetimi birimi, sendikalaşma konusunda } \\
\text { hem iş göreni hem de işletme sahiplerini } \\
\text { bilgilendirmeli ve sendikalaşmanın turizm } \\
\text { işletmelerinde de yaygınlaşması } \\
\text { sağlanmalıdır. }\end{array}$ \\
\hline $\begin{array}{l}\text { İş Değerleme } \\
\text { Yapılmadan Ücret } \\
\text { Yönetimi Sürecinin } \\
\text { Başlatılması }\end{array}$ & $\begin{array}{l}\text { Diğer tüm sektörlerde olduğu gibi turizm } \\
\text { sektöründe de işletmelerin ücret belirleme } \\
\text { politikaları, iş değerleme sürecine istinaden } \\
\text { başlatılmalıdır. Bu da insan kaynakları } \\
\text { yönetimi birimi tarafından yapılmalı ona göre } \\
\text { ücret belirlemeye gidilmelidir. }\end{array}$ & $\begin{array}{l}\text { İyi bir iş değerlemesi, ücret belirlemede } \\
\text { işin niteliğine göre ücret belirlemek } \\
\text { açısından faydalı olacaktır. Bu da iş } \\
\text { görenlere eşit ve adil bir ücret yönetimiyle } \\
\text { yönetildiklerini hissettirecek ve bu tür } \\
\text { sorunların oluşumunu engelleyecektir. }\end{array}$ \\
\hline $\begin{array}{c}\text { Sigortasız Kaçak İşçi } \\
\text { Sorunu }\end{array}$ & $\begin{array}{l}\text { Turizm işletmelerinde yoğun sezonlarda belli } \\
\text { aralıklarla sigortasız kaçak işç istihdam } \\
\text { edilebilmektedir. Bu da daimi iş görenlerin }\end{array}$ & $\begin{array}{l}\text { İnsan kaynakları yönetimi birimi, kaçak } \\
\text { işçi istihdam etme konusunda işletme } \\
\text { sahiplerini bilinçlendirmeli ve ucuz }\end{array}$ \\
\hline
\end{tabular}




\begin{tabular}{|c|c|c|}
\hline & $\begin{array}{l}\text { ücretlerini olumsuz yönde etkilemektedir. } \\
\text { İnsan kaynakları yönetimi birimi bu durum } \\
\text { karşısında net duruş sergilemeli ve bu tür } \\
\text { işçileri işletmelerde istihdam ettirmemelidir. }\end{array}$ & $\begin{array}{l}\text { işçilerin işletmeye daha fazla maliyetli } \\
\text { olabileceği konusunu onlara anlatmalıdır. } \\
\text { Bununla birlikte turizm işletmelerinde } \\
\text { kaçak ve sigortasız işçi istihdam etme } \\
\text { defteri kapatılmalıdır. }\end{array}$ \\
\hline $\begin{array}{r}\text { Doğru İş } \\
\text { Yön } \\
\text { Seçil }\end{array}$ & $\begin{array}{l}\text { Turizm işletmelerinde insan kaynakları } \\
\text { yönetimi birimi, iş değerleme ve ücret yönetimi } \\
\text { sürecini yönetirken iş değerleme } \\
\text { yöntemlerinden işin niteliğine göre doğru olanı } \\
\text { seçmekle yükümlüdür. Bu da iş değerleme } \\
\text { sürecini profesyonel bir şekilde yönetebilecek } \\
\text { kişiler tarafından yapılmalıdır. }\end{array}$ & $\begin{array}{l}\text { İş değerleme yöntemi insan kaynakları } \\
\text { yönetimi birimi tarafından doğru } \\
\text { seçildiğinde ücret yönetimi süreci etkin bir } \\
\text { şekilde işleyecek ve işletmenin verimliliği } \\
\text { artacaktır. }\end{array}$ \\
\hline $\begin{array}{l}\text { İş Değerleme } \\
\text { Yapılırken İş̧ } \\
\text { Dışındaki Faaliyetleri } \\
\text { Değerlendirme }\end{array}$ & $\begin{array}{l}\text { İş değerleme süreci, sadece işin } \\
\text { değerlendirildiği bir süreçtir. İş değerlemesi } \\
\text { yapılırken o işte çalışan iş göreni de } \\
\text { değerlendirmeye almak karşılaşılan en yaygın } \\
\text { sorunlardandır. }\end{array}$ & $\begin{array}{l}\text { Turizm işletmelerinde insan kaynakları } \\
\text { yönetimi birimi tarafından yapılan iş } \\
\text { değerleme sürecinde, sadece iş } \\
\text { değerlendirilmeli, o işi yapan iş görenler } \\
\text { değerlendirmeye alınmamalıdır. }\end{array}$ \\
\hline
\end{tabular}

Kaynak: Rock ve Berger, 1991; Özdemir ve Akpınar, 2002; French, 2003; Martocchio, 2004; Yenipınar, 2005; Armstrong, 2009; Akoğlan Kozak, 2012 ve Şahin, 2015'den yararlanılarak yazarlar tarafından oluşturulmuştur.

İş değerleme ve ücret yönetimi sürecinde karşılaşılan sorunlar genel hatlar itibariyle; uygun ücret sisteminin seçimi, personel devir hızının yüksek olması, turizm sektörünün mevsimselliği, turizm işletmelerinde fazla mesailerin ücrete yansıtılmaması, iş değerleme yönteminin doğru seçilmemesi ve turizm işletmelerinde sendikalaşmanın yok denecek kadar az olması gibi sıralanabilir. Bu sorunlara karşı insan kaynakları yönetimi birimi, ücret yönetimi sürecini yönetmek adına insan kaynakları yönetimi birimine alınan personeli titizlikle seçmelidir. Bunun dışında, yaşanan sorunların çözümünde işletmenin yapısı ve faaliyet alanı üst yönetim tarafından dikkate alınarak çözüm yollarına başvurulmalıdır.

\section{SONUÇ VE ÖNERILLER}

Ücret yönetimi, insan kaynakları yönetiminin en temel görevlerinden ve işlevlerinden birini oluşturmaktadır. Çünkü ücret yönetimi, işletme verimliliği ile doğrudan ilişkili bir konudur. Zira gelişmiş insan kaynakları yönetimi metotları, ücretleri işletmenin her alanı ile ilişkilendirmekte ve sahip olduğu niteliklerden dolayı ücrete anahtar rol görevini yüklemektedir. İşletmelerin insan kaynakları yönetimi departmanları, birbirinden farklı birçok ücret türüne göre şekillenen ücret yönetimi işlevini yerine getirirken, kendi işletme yapı ve kültürüne en uygun olan ücret sistemlerini seçmekte ve uygulamaya koymaktadır.

Turizm işletmelerinde insan kaynakları yönetimi birimi tarafından yönetilen iş değerleme ve ücret yönetimi süreci ile ilgili karşılaşılan sorunları ortaya koymayı amaçlayan bu çalışma, sektördeki insan kaynakları yöneticileri için 1şık olabilecek ve daha sonra yapılacak uygulamalı ve teorik çalışmalara da kaynak niteliği taşıyabilecektir. Bu bağlamda turizm işletmelerinde insan kaynakları yönetimi işlevi olarak iş değerleme ve ücret yönetimi hakkındaki en genel sorun, bu konudaki araştırma boşluğu olduğudur. Bu çerçevede bundan sonraki yapılacak çalışmalarda, turizm işletmelerinde iş değerleme ve ücret yönetimi sürecini gerçekleştiren personel ve işletmedeki diğer personelin katılımlarıyla gerçekleştirilecek ve sorunları açı/kapalı uçlu sorularla ölçmeyi amaçlayan uygulamaları kapsayabilir. Bu sayede sorunlara yeni bakış açıları getirilerek çözüm önerileri genişletilebilir.

Turizm işletmelerinde insan kaynakları yönetimi departmanlarının ücret yönetimi sürecinde yaşanan/yaşanabilecek sorunların kaynağını araştırarak sorun çıkmadan önce ücret yönetimine 
dair yukarda ifade edilen çözüm önerilerini uygulamak, işletmenin yararına olacaktır. Bu önlemlerin alınmasına 1şık tutacak bir araştırma önerisi de her bir turizm işletmesi türünden örneklem alınarak ücret yönetimi sürecinde Tablo 1 'de belirtilen ve diğer yaşanan veya yaşanabilecek potansiyel sorunların sektör temsilcileri tarafından ortaya konmasını sağlamak ve çözüm önerilerini genişletmek olabilir. Bir diğer araştırma önerisi de otel işletmelerinde uygulanan ücret yöntemlerinin uygulamalı bir çalışma ile ortaya koymak, buna ek olarak sayfiye ve kıyı olmak üzere karşılaştırmasını yapmak olabilir.

İş değerleme süreci, ücret yönetimi sürecinin belirleyicisi konumundadır. Bu nedenle turizm işletmelerinde iş değerleme süreci, insan kaynakları yönetimi birimi tarafından profesyonelce ele alınarak etkin ve verimli bir şekilde yönetilmelidir. İş değerleme yöntemi doğru seçilmeli ve iş değerlemede sadece iş değerlendirilmelidir. Bunun yanında iş değerlemesini yapacak profesyonel kişiler aracılığıyla bu süreç yönetilmelidir. İş değerleme ve ücret yönetimi süreci yönetilirken turizm işletmelerinin özellikleri dikkate alınmalıdır.

Söz konusu öneriler dâhilinde varılabilecek genel bir yargıya göre iş değerleme ve ücret yönetimi, turizm işletmeleri için stratejik öneme sahip bir insan kaynakları yönetimi işlevidir. Bu bağlamda turizm sektörünün yapısı gereği iş değerleme ve ücret yönetimi sürecinin etkin ve verimli bir şekilde gerçekleştirilmesi, işletmede karşılaşılabilecek sorunların en aza indirilmesi veya ortadan kaldırılması için önemli rol oynamaktadır. Uygun ücret sisteminin seçimi, fazla mesailerin ücrete yansıtılması ve turizm işletmelerinde sendikalaşmanın yaygınlaşması gibi konularda insan kaynakları yönetimi birimi öncülük ederek turizm sektöründe genel olarak karşılaşılan bu sorunların ortadan kaldırılmasına katkı sağlayabilir. Sonuç olarak, turizm işletmeleri yöneticilerine ve turizm işletmeleri örneğinde hizmet sektörünün diğer kuruluşlarındaki yöneticilere getirilebilecek en önemli öneri, iş değerleme ve ücret yönetimine gereken önemin verilmesi ve bu konuda iş değerleme ve ücret yönetimi sürecini iyi yönetebilecek insan kaynakları yönetimi departmanlarını destekleyici kararlar alınmasıdır. Bu kararlar alınırken turizm işletmesi bazında çalışanlar, sektör bazında işletmeler, kamu bazında ilişkili olunan yasal yükümlülükler, pazarlama ve rekabet bazında aynı faaliyetteki diğer işletmeler ve genel olarak işletmenin bulunduğu bölgedeki toplum düzeni ve yerel halk göz önünde bulundurulmalıdır. $\mathrm{Bu}$ bileşenler bir bütün olarak değerlendirilmeli ve her birinin beklentilerine göre hareket edilmelidir.

\section{KAYNAKÇA}

Akıncı, Z., Kasalak, M. A. ve Yurcu, G. (2015). Konaklama İşletmelerinin İşs Değerleme Süreçlerinde Puanlama Yönteminde Hedef Programlama Tekniğinin Kullanılması, Journal of Tourism Theory and Research, 1 (1): 41-55.

Akoğlan Kozak, M. (2012). Otel İşletmelerinde İnsan Kaynakları Yönetimi ve Örnek Olaylar, (4. Baskı). Ankara: Detay Yayıncllık.

Aksoy, B. (2005). Bilgi Teknolojilerinin Yarattığı Örgütsel Değişim: Nasıl Bir İnsan Kaynakları Yönetimi, Bilgi Dünyası, 6 (1): 58-77.

Akün, F. (1984). İş Değerlendirmesinin Temelleri. İstanbul: Kutyay Yayınevi.

Armstrong, M. (2009). Armstrong's Handbook of Human Resource Management Practice. London: Kogan Page.

Ataay, İ. D. (1990). İş Değerleme ve Başarı Değerleme Yöntemleri. İstanbul: Küre Matbaası. 
Ataay, İ. D. ve Acar, A. C. (2008). Ücret yönetimi, (Editörler) C. Uyargil, İ. D. Ataay, A. C. Acar, A. O. Özçelik, Ö. Sadullah, G. Dündar ve L. Tüzüner: İnsan Kaynakları Yönetimi içinde (ss.399-511) İstanbul: Beta Yayınları.

Benligiray, S. (2003). Ücret Yönetimi. Eskişehir: Anadolu Üniversitesi Yayınları, No: 1462.

Budak, G., Arpacı, S. Ç. ve Tolay, E. (2017). Performansa ve Yetkinliğe Dayalı Ücret ve Ödül Yönetimi Arasındaki Bağlantılar, Ömer Halisdemir Üniversitesi İktisadi ve İdari Bilimler Fakültesi Dergisi, 10 (4): 15-34.

Can, H., Akgün A. ve Kavuncubaşı, Ş. (1998). Personel Yönetimi. Ankara: Siyasal Kitabevi.

Çetin, C., Dinç Özcan, E. ve Arslan, M. L. (2014). İnsan Kaynakları Yönetimi. İstanbul: Beta Basım Yayı Dağıtım.

Dağdeviren, M., Akay, D. ve Kurt, M. (2004). İş Değerlendirme, Faktör Derece Puanlarının Belirlenmesinde Hedef Puanlama Yönteminin Kullanılması, Gazi Üniversitesi MühendislikMimarlık Fakültesi Dergisi, 19 (1): 89-95.

Decenzo, D. A. and Robbins, S. P. (1988). Personnel/Human Resource Management (3rd Edition). Prentice-Hall of India Pvt. Limited.

Demir, R. ve Acar, A. C. (2014). İş Ahlakı Açısından Ücret Yönetimi Sistemi, İş Ahlakı Dergisi, 7 (1): 95-148.

Elizur, D. (1980). Systamatic Job Evaluation and Comparable Worth. Vermond: Gower Publishing Company Limited.

England, P. (2000). Equal Pay for Equal Work: Job Evaluation in an Evolving Social Norm, Journal of Economic Issues, 34 (1): 1-19.

Eraslan, E. ve Arıkan, A. (2004). Ücretlendirmede Puan Yöntemi, Kıdem ve Başarı Değerlendirme: Bir İmalat İşletmesinin İç Üretim Bölümünde Uygulama, Gazi Üniversitesi Mühendislik ve Mimarlık Fakültesi Dergisi, 19 (2): 139-150.

Erbaş, E. ve Dursun, M. (2016). İş Değerleme, (Editörler) Şahin Perçin, N., Güzel, B. ve Aydın Tükeltürk, Ş.: Turizm İşletmelerinde İnsan Kaynakları Yönetimi ve Uygulamaları içinde (ss.316-330) İstanbul: Beta Basım Yayım Dağıtım.

Erdem, B. (2004). Otel İşletmelerinde İnsan Kaynakları Planlamasının Yeri ve Önemi, Balıkesir Üniversitesi Sosyal Bilimler Enstitüsü Dergisi, 7 (11): 35-54.

Ergül, H. F. (2006). Kurumlarda Ücret, Ücret Sistemleri ve Ücret-Başarı İlişkisi, Elektronik Sosyal Bilimler Dergisi, 5 (18): 92-105.

Ertürk, M. (2006). İşletme Biliminin Temel İlkeleri, (6. Baskı). İstanbul: Beta Basım Yayım Dağıtım.

French, W. L. (2003). Human Resources Management. Boston: Houghton Mifflin Company.

Gürüz, D. ve Özemir Yaylacı, G. (2009). İletişimci Gözüyle İnsan Kaynakları Yönetimi. İstanbul: MediaCat. 
ILO. (1986). Job Evaluation. İstanbul: İstanbul Üniversitesi İşletme Fakültesi Yayınları, Yayın No: 166.

Isaac, A. (1940). İşletme İstisadı (Cilt I). (O. Tuna, Çev.) İstanbul: İstanbul Üniversitesi İktisat Fakültesi Yayını.

Işığıçok, Ö. (2011). Ücret Teorisi-Politikası-Yönetimi-Sistemleri (2. Baskı). Bursa: Marmara Kitabevi Yayınları.

Kelly, R. L. (1972). Job Evaluation and Pay Plans. New York: McGraw Hill Book.

Martoccohio, J. J. (2004). Strategic Compensation. New Jersey: Pearson Prentice Hall.

Milkovich, G. T., Newman, J. M. and Gerhart, B. (2011). Compensation (4th ed.). New York: McGraw Hill.

Milkovich, G. T. and Boudreau, J. W. (1991). Human Resource Management. Homewood: Richard D. Irwin, Inc.

Milkovich, G. T. and Newman, J. M. (1984). Compensation. Business Publications Inc.

Özdemir, E. ve Akpınar, A. T. (2002). Konaklama İşletmelerinde İnsan Kaynakları Yönetimi Çerçevesinde Alanya'daki Otel ve Tatil Köylerinde İnsan Kaynakları Profili Kocaeli Üniversitesi Sosyal Bilimler Enstitüsü Dergisi, 3 (2): 85-105.

Özgen, H., Öztürk, A. ve Yalçın, A. (2005). İnsan Kaynakları Yönetimi. Adana: Nobel Kitabevi.

Pelit, E. (2015). Turizm İşletmelerinde İnsan Kaynakları Yönetiminin Önemi, (Editör) Pelit, E.,: Turizm İşletmelerinde İnsan Kaynakları Yönetimi içinde (ss.61-127) Ankara: Grafiker Yayınları.

Rock, M. L. and Berger, L. A. (1991). The Compensation Handbook. USA: McGraw-Hill.

Şahin, L. (2010). İnsan Kaynakları Yönetimi'nde Ücretlendirme Fonksiyonunun Analizi, Kamu-IŞ̧ Dergisi, 11 (2): 129-164.

Şahin, S. (2015). Turizm İşletmelerinde İş Değerleme ve Ücret Yönetimi, (Editör) Pelit, E.: Turizm İşletmelerinde İnsan Kaynakları Yönetimi içinde (ss.349-387) Ankara: Grafiker Yayınları.

Tahiroğlu, F. (2002). Düşünceden Sonuca İnsan Kaynakları. İstanbul: Hayat Yayıncılık.

Tekin, V. N. ve Şenol, L. (2013). İşletme, Kavramlar-illkeler-İşlevler. Ankara: Seçkin Yayıncılık.

Webster, A. (2014). Wage Differentials and Their Determinants in US Tourism and TourismAssociated Industries, Tourism Economics, 20 (4): 695-725.

Wu, X., Sturman, M. C. and Wang, C. (2013). The Motivational Effects of Paying Fairness: A Longitudinal Study in Chinese Star-Level Hotels, Cornell Hospitality Quarterly, 54 (2): 185-198.

Yalçın, A. S. (1999). Personel Yönetimi. İstanbul: Beta Basım Yayım Dağıtım.

Yenipınar, U. (2005). Otel İşletmelerinde Ücretlendirme: İzmir İli 4-5 Yıldızlı Otel İşletmelerinde Bir Analiz, Dokuz Eylül Üniversitesi Sosyal Bilimler Enstitüsü Dergisi, 7 (3): 148-176.

Yüksel, Ö. (1998). İnsan Kaynakları Yönetimi. Ankara: Gazi Kitapevi. 